\title{
Do You Understand What You're Reading? Lasting Religious Education as a Response to the Contemporary Challenges in Reaching the World for Christ
}

\author{
Mario Kushner \\ Baptist Church in Virovitica \\ mariokushner1689@gmail.com
}

UDK:2-47;2-75;27-1

Original scientific paper

https://doi.org/10.32862/k.14.1.5

\begin{abstract}
The fundamental thought of the Lausanne congresses and The Cape Town Commitment (TCTC) statement as the final product of the third congress, could be summarized by these words: "The Church needs to evangelize the world." From that battle cry come the challenges of knowing the Gospel and mastering the skills necessary for implementing that plan. This article points out that both challenges can be overcome only through a consistent educational ministry within local fellowships of believers.
\end{abstract}

Keywords: church, education, teaching, 2 Tim. 2:2, Eph. 4:11-12, evangelism, doctrine

\section{Introduction: The Global Call to Know and To Do}

The subtitle to The Cape Town Commitment (TCTC), which is, "A Confession of Faith and a Call to Action," reveals that doctrine and action are both different sides of the same coin which is also evident in the way that the New Testament (NT) authors formed their inspired writings. ${ }^{1}$ Correct belief inspires correct action and correct action implies correct belief; one does not go

1 Eg., the books of Romans, Galatians, and Ephesians begin with a segment on doctrine, and end with the practical applications of the first segment. 
without the other. On the contrary, they complement and facilitate each other. Christians who possess correct knowledge of Biblical truths are more prone to diligent living in the things in which these truths have called them. Subsequently, Christians who act upon their faith are never fully content with their level of knowing God and his Word; instead, studying Christian doctrines is actually included in their practices.

Christian teaching and striving (doctrine and action) are equally important elements in the endeavor of reaching the godless world with the Good News of forgiveness in Jesus Christ. Only a church that is free from wrong beliefs can offer the liberating truth to its surroundings. Thus, it is only the church which lives what it teaches that can catch the attention of the world which is filled with superficiality and duplicity, to the point that the world can only be intrigued by the authenticity of a church which is enacting its teaching with no compromise. Unfortunately, neither one nor the other are free of problems in today's Christianity.

\section{A Twofold Problem in Christianity}

Since it is a fact that the TCTC is calling the Church to reach the world with the Gospel, ${ }^{2}$ the desire to answer this call brings with it at least two elementary challenges:

1) Each member of a local church needs to be accurately familiar with the doctrinal contents of the Gospels;

2) Each member of a local church needs to possess and to continually develop their skills of communicating the Gospel effectively.

The current situation with Croatian Christians seems to point to the fact that the younger members seem to be vulnerable against the first challenge, while the older members seem to be more susceptible to the problems brought on by the second challenge. Younger Christians lack knowledge, while mature Christians lack skill. The problem is not that they have never acquired the skill but in the fact that the world has changed and this change has rendered the old methods ineffective in communicating with the new culture.

Modern society brings along some new phenomena that the previous generations have never encountered (eg., the ubiquity of Internet-based social networks and using the "meme" genre for sharing ideas). Even those who belong to the socalled Generation Y (people born between 1980 and 1990) are beginning to lose touch with the next generation (Generation $\mathrm{Z}$ ), which means that the cultural gap

2 The Lausanne Congresses have been called with the "intent of reaching the world with the Gospel" (TCTC 2011, Preamble). 
between today's children and members of Generation X (people who were born between 1960 and 1980) are beginning to show signs of being insurmountable. Thus, Christians older than 40 are encountering problems in communicating with the younger population and even in reaching their own children for Christ. Therefore, older Christians need to update their outreach and communication methods.

On the other hand, the failure of older generations to understand and awaken the interesting of the young is probably the cause of increasing worldliness among the young people in churches. The consequence of this worldliness is either an incorrect and superficial knowledge of the Bible or, even worse, complete unfamiliarity with it. Even those young Christians who have understood enough of the Gospel to accept it and receive salvation often do not know what is it that makes up the Good News which they are supposed to spread further.

It is not rare for young Christians, who are intimidated with their own ignorance, to make one (or both) of two mistakes. First, they think that it is enough to live "differently" and to proclaim the Gospel through their good works. In such cases, we often hear the phrase that is so corny that it is almost impossible to trace its source, i.e., the person who first said/wrote it, "Always preach the Gospel, and if necessary, use words." 3

Secondly, they substitute the clear statement of basic elements of the Gospel with sharing their testimonies (which, although they are an interesting and lively representation of the working of the Gospel, they are not the Gospel itself). TCTC recognizes this danger and undeniably claims the following, "We must proclaim the truth. Spoken proclamation of the truth of the gospel remains paramount (emphasis added) in our mission. This cannot be separated from living out the truth. Works and words must go together." (TCTC IIA:1A2).

The paradox of widespread so-called "Biblical illiteracy" amid extremely high technological and Internet literacy among young people is hard to understand. The availability of good quality Bible study materials online is no guarantee that young Christians will necessarily utilize these advantages. On the contrary, it seems that so-called Biblical illiteracy has become a growing problem in the last several decades. Five years ago, North American regional director of Lausanne International, Ed Stetzer (2015) wrote about this problem, "Study after study in the last quarter-century has revealed that American Christians increasingly don't read their Bibles, don't engage their Bibles, and don't know their Bibles. It's obvious: We are living in a post-Biblically literate culture."

He blames the problem on the way Christians read the Bible, if they read it at all. Thus, he offers the following solution (Stetzer, 2015):

3 For the authorship of the statement, as well as the analysis of the idea that it represents, see: Arpin-Ricci (2012), anonymous (2011), Stanton (2012), i Hall (2019). 
It's not just that we read our Bibles, but the way we read our Bibles that increases biblical literacy. I believe there's a link between biblical illiteracy and our habit of fracturing the Bible into pieces and parts. We read a verse here, a chapter there. We need a quick verse for anxiety, so we run to Matthew 6:34 ("Take no thought about tomorrow, for tomorrow will take thought about the things of itself”). We need another verse about fear, so we jump to 1 John 4:18 ("There is no fear in love, but perfect love casts out fear"). These verses can help when we're dealing with life's difficulties, but a steady diet of verses and chapters digested in this way amounts to spiritual "fast food" from our McBibles. We need a whole Bible approach to Bible reading and study.

It would be wrong to think that this "Biblical illiteracy" is a plight that is only affecting the United States and not our country, as well. This is seen in the fact that the topic of recently published issue 45 of the magazine "Duhovno vrelo" (Spiritual wellhead) (Punda 2019) was in fact "The Challenge of Biblical Literacy in Contemporary Church."

It is also symptomatic that some steps in good direction towards increasing elementary Biblical literacy have recently been made by the Bible Institute in Zagreb with their evening lectures (eg., "The Bible - What You Probably Didn't Know" and "How (Not) to Get Lost in the Bible"), and by the Theological Bible Academy from Krapina with their extracurricular program called, BIBL.O.S. (Biblical Education of Co-Workers), which is utilized in churches across the country in order to teach basics of the Bible.

The issue of being unfamiliar with elementary Christian doctrines is addressed by Grenz and Olson $(2018,9)$ with these words, "Many Christians today not only are uninformed about basic theology but even seem hostile to it." Harmful consequences of such attitude towards theology got the authors (Grenz and Olson, $2018,10)$ concerned that "...individual Christians who lack theological literacy and acumen will be tossed about by every wind of doctrine that comes sweeping through our media-dominated culture....all kinds of strange doctrines-'other gospels'-are being promoted and accepted by Christians unequipped to evaluate them." So if we want to reach the world with the Gospel, first we must equip those who are going to do it. Young Christians lack basic knowledge, while the older generation seems to be in need of new skills. TCTC has a lot to say about this, while repeatedly emphasizing the need for equipping believers.

In the light of post-modernistic pluralism in the public scene, TCTC emphasizes the importance of equipping intellectuals for public discourse:

We need to identify, equip and pray for those who can engage at the highest intellectual and public level in arguing for and defending biblical truth in the public arena (IIA:2A1).

We urge Church leaders and pastors to equip all believers with the courage and 
the tools to relate the truth with prophetic relevance to everyday public conversation, and so to engage every aspect of the culture we live in (IIA:2A2).

Talking about evangelizing in the workplace, the CTCT recognizes the need for equipping Christian workers:

In spite of the enormous evangelistic and transformational opportunity of the workplace, where adult Christians have most relationships with non-Christians, few churches have the vision to equip their people to seize this. (IIA:3A)

We challenge pastors and church leaders to support people in suchministry - in the community and in the workplace - 'to equip the saints for works of service [ministry]' - in every part of their lives. (IIA:3B)

We need intensive efforts to train all God's people in whole-life discipleship, which means to live, think, work, and speak from a biblical worldview and with missional effectiveness in every place or circumstance of daily life and work. (IIA:3C)

There is a danger of understanding these statements as pertaining to regular public teaching through sermons during Sunday worship services. However, that cannot be what the CTCT is referring to, because a single sermon (which lasts anywhere between half an hour and an hour) once a week is not a sufficient amount of teaching through which the pastor can equip the young (to understand doctrine) and the old (to gain skills). If the sermon is an expository one, it is limited by the theology of the book that is being interpreted. If not, it is then limited by the pastor's personal interests and the things he thinks are needed by the flock. That is why equipping believers needs to take on some different form.

\section{Ongoing Education as the Solution}

Pastors need to come up with and to implement a comprehensive model of teaching through which they will be able to fulfill their task of equipping believers. This has to do with the need for formal theological and practical teaching in the local church for the purpose of equipping believers for the ministry of proclaiming the Gospel to the world. There needs to be additional teaching in church aside Sunday sermons.

Sermons are aimed at the heart, while formal education is aimed at the mind. Believers often possess the zeal but lack the Biblical knowledge and practical skills. That is why, apart from the Sunday sermons, local churches need to also have some sort of formal Biblical, theological, and practical education. We need to be cautious so as not to delegate this role of the church to theological school, because it is they who equip theologians, pastors, and preachers (or all three in one). 
However, not all believers are theologians, pastors, or preachers. And yet, all believers need to be equipped. So, these theologians, pastors, or preachers (who end up finishing their preparations in theological schools) need to equip believers from their churches who might not necessarily require education in original $\mathrm{Bi}$ blical languages, but they very much do need some other skills and know-how.

Some people do not know what they believe. Some know what they believe, but do not know why they believe it. Tradition may be good and rooted in the Bible, but if the practitioners' practice is divorced from theory, this means that human tradition supersedes the Word of God. This is why people need to be taught for more than half an hour a week.

\section{The Biblical Argument for Church Education}

The limitations of this article do not allow for a comprehensive review, but it will suffice to emphasize two New Testament passages which are often used when dealing with this subject: Eph. 4:11-12 and 2 Tim. 2:2. In the first passage, the apostle Paul provides a short explanation for the existence of pastoral ministry, "And He (i.e., Christ) gave some as apostles, and some as prophets, and some as evangelists, and some as pastors and teachers, for the equipping of the saints for the work of service, to the building up of the body of Christ..." In the other passage, the same author tells his "apprentice" Timothy, "The things which you have heard from me in the presence of many witnesses, entrust these to faithful men who will be able to teach others also." In the rest of the article, we will provide some insight as to the connection between these two passages as tied in with ongoing church education.

\section{Ephesians 4:11-12}

In the context which deals with the role of the individual within the Christian collective (4:1-16), we notice four fundamental roles, i.e., ministries in verse 11: apostles, prophets, evangelists, and shepherds/teachers. ${ }^{4}$ These four categories of people have been "given/gifted" ( $\varepsilon \delta \omega \kappa \varepsilon v)$ to the church in order to prepare

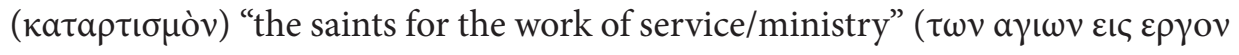

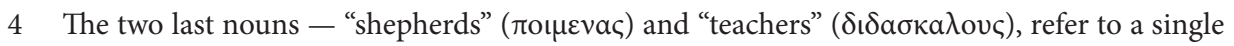
role, ie., ministry. "The two functions are regarded as coinciding and combining in the one settled guardian of a local flock" (Moule 1977, 110). However, Daniel Wallace (1996, 284) emphasizes that this is not necessarily just one spiritual gift being described using two words, but that we're also not obligated to accept the option that these are "two completely separate groups", either. He explains that, since pastors are tasked with teaching in church, but also not all teachers in church are pastors, Paul is probably talking about pastors, who are a subgroup of teachers (Wallace 1996, 284). Accordingly, Wallace maintains that these two nouns are used to describe one single group of people in this passage. 


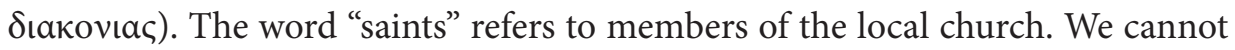
overemphasize the importance of this passage's teaching that "the work of service/ministering" is performed by the members of the church. Therefore, it is not the church leaders who are supposed to be involved in all ministries required for proper operations in a local church; instead, they ought to equip the other believers for that. Instead of the "clergy" doing the ministry while the rest of the church members remain akin to observers of service users, each member has their place and their role. The correlation between this passage's teaching and the fulfillment of the basic role of the church has been marvelously emphasized by Paul Tautges $(2009,53)$ :

Authentic biblical ministry works toward the goal of seeing the local church function as a healthy body of believers running the Christian race as a unified team while being intentionally equipped by Spirit-gifted men (emphasis added). As a result, each member is prepared to carry out his or her God-appointed role in the work of building up the whole church. ${ }^{5}$

Still, we need to bear in mind that the tasks of the leaders in the church differ from the tasks of other members. Pastors/elders are primarily tasked with equipping others. In their exhaustive paper on church education, Parrett and Kang $(2009,41)$ go on to explain:

...while every member of the body of Christ has work to do, God has given leaders to the church who are specifically charged with and gifted for equipping those members to do that appointed work. Said otherwise, the gifted leaders have a vitally formative task to fulfill in helping the body mature and function properly, a goal that requires that each member of the body be able and willing to do its uniquely appointed part.

In situations when the church (whether it is an entire denomination or an individual local congregation) has accepted the view whereby it divides believers into the clergy and laymen, where the clergy are expected to lead the church and perform all ministries and the laymen are expected to placidly follow and financially support the clergy and their work, "the church and the ministry suffer" 6 (cf. Boice 1997, 135). Even if we hold on to the different names for these two groups, the difference is certainly not about who performs the ministry but about who performs the ministry in what way. In this respect, "The laity serve the church and the world. The clergy serve the laity, particularly in helping them to develop

5 "Authentic biblical ministry works toward the goal of seeing the local church function as a healthy body of believers running the Christian race as a unified team while being intentionally equipped by Spirit-gifted men. As a result, each member is prepared to carry out his or her God-appointed role in the work of building up the whole church." 
and use their gifts" (Boice 1997, 135). ${ }^{7}$

\section{First Letter to Timothy 2:2}

The thing that is obviously lacking in many churches today, according to the instruction given to young pastor Timothy, is equipping those who will go on to equip others - pastors should be equipping church leaders, who should then go on to equip the others in the local church. In other words, pastors should make sure there is somebody to replace them and that the church would not be left without teachers in their absence, be it temporary or permanent. A similar idea, which takes away the monopoly for serving from the hands of pastors, is seen when Christ gave shepherds to the church so they would equip all other members of the local church for the work of service (Eph. 4:11).

Probably the most significant insight regarding this passage is the fact that the apostolic teaching ("The things which you have heard from me") needs to be passed on and explained, as opposed to assuming that it is being understood. In commenting this chain of passing on the doctrine, John Macarthur $(1995,42)$ erroneously concludes that:

It is for that primary purpose that Bible schools, Christian colleges, and seminaries are founded and that books and commentaries are written-to prepare dedicated Christian men and women for effective service to the church and in the world. And within that broader purpose is the narrower one of giving special attention to raising up new generations of mature spiritual leaders who are uniquely trained and assigned to carefully guard and faithfully articulate God's truth.

The first part of claim is heading up the wrong trail because it disregards the fact that apostle Paul's words were addressed to Timothy as a pastor/elder, as opposed to a professor (cf. 1 Tim. 1:3; 4:6-16; 5:22; 6:11-14; 2 Tim. 1:6,13-14; 2:3-7; $2: 22-26 ; 4: 1-5)$. Also, Timothy's task of equipping those who will be involved in equipping others was supposed to take place in the confines of the local church, and not a higher educational institution (cf. 1 Tim. 1:3; 3:14-15).

There is no doubt that there is a purpose for theological schools, but their role does not negate that of the local church. In the best case scenario, seminaries need to continue and complement the education which was started in the church. The scope of this article does not allow for a detailed treatise of the topic, neither theologically or historically, but suffice it to say that God has entrusted the local church with the task of equipping its ministers and all other members. If the Great Commission calls the church of Christ to make disciples, then local churches 
should look more like educational centers. For various reasons, the churches have relegated this responsibility to theological seminaries.

A better and more precise insight is provided by John Kitchen $(2009,343)$ :

"Success in ministry, according to this verse, is measured by two standards. First, the accuracy of the message conveyed to another generation. Second, the ability of the next generation to pass this message accurately to yet another generation. Paul envisioned this success spanning at least four generations: himself, Timothy, "faithful men," and "others also." This is the pattern of lifeto-life transference that measures the success of the church in all ages.

We can find some help in understanding this truth in the analogous principle which applies to other fields of human activity as well. For example, divers exercise underwater because being in the water is a unique experience which cannot be replicated on land. In a similar fashion, astronauts are trained in the desert (which resembles the conditions they might encounter on, say, Mars) instead of the jungle, because those two geographical contexts are extremely different. Following the same logic, it is impossible to equip people for serving in church outside of the church.

Local churches tend to send young people in their prime into studies, where they "drown" once they "get into the water." A much better analogy would be if both the preparation for ministry and ministry itself were performed in the same environment - ie., in the local church.

Theological seminaries need to provide additional, advanced education after finishing elementary church education and before starting with ongoing church education. Do we dare consider the possibility that theological seminaries exist because the church isn't educating people? By applying this passage correctly, we will reach such a teaching atmosphere in local churches where "it is the entire church teaching and the entire church learning" (Gilbert 1962, 76). ${ }^{8}$

\section{Conclusion}

The concise subtitle of this paper is, Do You Understand What You Are Reading? and has been apologetically "lifted" from Acts 8:30-31 where the Ethiopian eunuch answers the apostle Phillip with the counter-question, "Well, how could I, unless someone guides me?" The question is rhetorical, and the assumed answer is, "Well, you cannot." There are some things that believers cannot understand without the help of specially educated and equipped teachers.

For those who have the ears to hear, this truth is very clearly communicating 
that believers in local churches need help in order to understand God's Word. The implication is that "each church member needs to continue being a student throughout their entire life" (Gilbert 1962, 77). This account tells us that Phillip was sufficiently familiar with Biblical teaching that he was able to serve the eunuch by explaining the meaning of the passage in Isa. 53:7-8 to him.

The lesson from this account for churches in Croatia today is clear, "Every believer should strive to be proficient in the Scriptures so that we, too, can...lead [people] to the Savior" (MacArthur 1994, 257). A half-hour sermon once a week is a minimum that the church should not settle for because not even Christ himself did only give his minimum for it.

Local church members ought to ask their spiritual leaders for more teaching throughout the week, not just one sermon on Sundays. Pastors/elders ought to invest their time and money into their own personal ongoing education, as well as the education of their "deputies," who should be helping them in the ongoing basic Biblical, and in due time, even advanced theological education of each member of the local church they serve in.

For starters, the Croatian denominational leaders who belong to Reformation heritage Christianity need to think about the "Sunday school for adults" model, which is widespread in Evangelical and Reformed churches all over the USA. If this particular model proves to be unsuitable for the cultural context of the European or Slavic culture, we need to figure out a model which might reach similar results (higher Biblical literacy and the subsequent spiritual maturity), and which would be more appropriate for our country.

\section{Bibliography}

Anonymous. 2011. "Did Francis really say, Preach the Gospel at all times and if necessary use words?" Focus on Campus. https://focusoncampus.org/ content/did-francis-really-say-preach-the-gospel-at-all-times-and-if-necessary-use-words.

Arpin-Ricci, Jamie. 2012. "Preach the Gospel at All Times?” Huffpost. https://www.huffpost.com/entry/preach-the-gospel-at-all-times-stfrancis_b_1627781.

Boice, James Montgomery. 1997. Ephesians - An Expositional Commentary. Grand Rapids: Baker Books.

Gilbert, W. Kent. 1962. As Christians Teach. Philadephia: Lutheran Church Press.

Grenz, Stanley J. and Olson, Roger E. 2018. Komu treba teologija? — Poziv na 
proučavanje Boga. Zagreb: Biblijski institut.

Hall, Sarah. 2019. "Preach the gospel at all times. Of necessity, use words." Premier Christianity Magazine. https://www.premierchristianity.com/Blog/ Preach-the-gospel-at-all-times.-Of-necessity-use-words.

Kitchen, John A. 2009. The Pastoral Epistles for Pastors. The Woodlands: Kress Christian Publications.

MacArthur, John. 1994. The MacArthur New Testament Commentary - Acts 1-12. Chicago: Moody Publishers.

MacArthur, John. 1995. The MacArthur New Testament Commentary - 2 Timothy. Chicago: Moody Publishers.

Moule, H. C. G. 1977. Studies in Ephesians. Grand Rapids: Kregel Publications.

Parret, Gary A. and Kang, S. Steve. 2009. Teaching the Faith, Forming the Faithful - A Biblical Vision for Education in the Church. Downers Grove: IVP Academic.

Punda, Goran (ed.). 2019. Duhovno vrelo, XI:45. Osijek: Izvori. https://issuu. com/milandreja/docs/duhovno_vrelo_br_45_2019_web.

Stanton, Glenn. 2012. "FactChecker: Misquoting Francis of Assisi." The Gospel Coalition. https://www.thegospelcoalition.org/article/factchecker-misquoting-francis-of-assisi/.

Stetzer, Ed. 2015. "Dumb and Dumber: How Biblical Illiteracy Is Killing Our Nation." Charisma Magazine. https://www.charismamag.com/life/ culture/21076-dumb-and-dumber-how-biblical-illiteracy-is-killing-ournation.

Tautges, Paul. 2009. Counsel Your Flock - Fullfilling Your Role as a Teaching Shepherd. Leominster: Day One Publications.

The Cape Town Commitment (TCTC). 2011. The Lausanne Movement.

Wallace, Daniel B. 1996. Greek Grammar Beyond the Basics. Grand Rapids, Michigan: Zondervan. 
Mario Kushner

\title{
Razumiješ li to što čitaš? - Trajno crkveno obrazovanje kao odgovor na suvremene izazove evangelizacije svijeta
}

\begin{abstract}
Sažetak
Temeljna misao Lausannskih kongresâ i Capetownskog iskaza o predanju, kao konačnog proizvoda trećeg kongresa, mogla bi se sažeti riječima "Crkva mora evangelizirati svijet”. Iz toga „borbenog pokliča“ proizlaze izazovi poznavanja Evanđelja i savladavanja vještinâ potrebnih za sprovođenje tog plana. Ovaj članak ističe da je oba izazova moguće savladati jedino kroz dosljednu službu obrazovanja unutar lokalnih zajednica vjernikâ.
\end{abstract}

